University of Nebraska - Lincoln

DigitalCommons@University of Nebraska - Lincoln

Faculty Papers and Publications in Animal

Science

Animal Science Department

1990

\title{
Myofibrillar Protein Turnover in Feed-Restricted and Realimented Beef Cattle
}

Steven J. Jones

University of Nebraska-Lincoln, sjones1@unl.edu

D. Starkey

University of Nebraska-Lincoln

Chris R. Calkins

University of Nebraska-Lincoln, ccalkins1@unl.edu

J.D. Crouse

ARD-USDA

Follow this and additional works at: https://digitalcommons.unl.edu/animalscifacpub

Part of the Animal Sciences Commons

Jones, Steven J.; Starkey, D.; Calkins, Chris R.; and Crouse, J.D., "Myofibrillar Protein Turnover in FeedRestricted and Realimented Beef Cattle" (1990). Faculty Papers and Publications in Animal Science. 575. https://digitalcommons.unl.edu/animalscifacpub/575

This Article is brought to you for free and open access by the Animal Science Department at DigitalCommons@University of Nebraska - Lincoln. It has been accepted for inclusion in Faculty Papers and Publications in Animal Science by an authorized administrator of DigitalCommons@University of Nebraska - Lincoln. 


\title{
MYOFIBRILLAR PROTEIN TURNOVER IN FEED-RESTRICTED AND REALIMENTED BEEF CATTLE ${ }^{1,2}$
}

\author{
S. J. Jones ${ }^{3}$, D. L. Starkey ${ }^{3}$, \\ C. R. Calkins ${ }^{3}$ and J. D. Crouse ${ }^{4}$ \\ University of Nebraska, Lincoln 68583-0908 and \\ Roman L. Hruska U.S. Meat Animal Research \\ Center, Clay Center, NE 68933
}

\begin{abstract}
The objective of this study was to determine the effect of feed restriction and repletion on myofibrillar protein turnover in cattle. Crossbred steer calves $(n=12)$ about $310 \mathrm{~d}$ of age were assigned randomly to a diet of com and silage that was 1) provided ad libitum for $146 \mathrm{~d}$ (ALC) or 2) restricted so steers gained $.2 \mathrm{~kg} / \mathrm{d}$ for $80 \mathrm{~d}$ but received ad libitum access to feed thereafter for $66 \mathrm{~d}$ (RFC). At 27, 55, 97, 118 and $146 \mathrm{~d}$ a 24-h urine sample and a blood sample were obtained. Urine was analyzed for $\mathrm{N}^{\tau}$ methylhistidine $\left(\mathrm{N}^{\top}-\mathrm{MH}\right)$, creatinine (C), urea nitrogen (UN) and total nitrogen (TN). Serum samples were analyzed for hydroxyproline (HYP), C and albumin (A). Body weights were lower $(P<.05)$ in RFC at 55, 97, 118 and $146 \mathrm{~d}$. Excretion of $\mathrm{N}^{\tau}-\mathrm{MH}$ was lower $(P<.05)$ in the RFC at 27 and $55 \mathrm{~d}$ but higher at $118 \mathrm{~d}$. Urinary $\mathrm{C}$ excretion was higher in ALC at the last four sample times. Urinary UN and TN excretion were lower $(P<$ $.05)$ in RFC at 55, 97 and $118 \mathrm{~d}$; urinary UN also was lower $(P<.05)$ at $\mathrm{d} 146$. Serum A was higher $(P<.05)$ in ALC at 55 and $118 \mathrm{~d}$, respectively. Serum HYP was higher $(P<$ .05 ) in RFC at 27 and $55 \mathrm{~d}$. Calculated myofibrillar protein breakdown rates (FBR) and fractional synthesis rates (FSR) were higher $(P<.05)$ in RFC at the last two sampling periods; FSR was lower for the RFC at the first sampling period. Realimentation after a period of feed restriction increased both synthesis and degradation of myofibrillar protein in beef cattle.

(Key Words: Protein Tumover, Protein Degradation, Methylhistidine, Restricted Feeding.)
\end{abstract}

J. Anim. Sci. 1990. 68:2707-2715

\section{Introduction}

Skeletal muscle is the major protein depot in beef cattle and functions as a protein reserve for whole-body metabolism (Daniel et al., 1977). Muscle protein accretion, defined as the net difference between protein synthesis and degradation, is the major reason for raising and producing meat animals. The primary mecha-

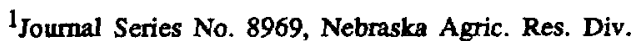
Inst. of Agric. and Nat. Resources.

${ }^{2}$ Technical assistance of Ruth Diedrichsen for HPLC analysis is appreciated.

3 Dept. of Anim. Sci.

${ }^{4}$ Roman L. Hruska U.S. Meal Anim. Res. Center. ARS, USDA.

Received June 29, 1989.

Accepted January 31, 1990.
}

nism of postnatal muscle growth in beef cattle is the accretion of protein.

Nutritional status has a major impact on the rate of muscle protein turnover. Millward et al. (1975) observed that muscle protein tumover rates decreased when rats were fed a lowprotein diet. However, upon realimentation to an adequate diet, rapid growth occurred concomitant with high rates of both muscle protein synthesis and breakdown. Haverberg et al. (1975) demonstrated that nutritional restrictions that retarded the normal rate of growth were associated with decreased rates of synthesis and degradation.

Measurement of urinary $\mathrm{N}^{\tau}$-methylhistidine ( $\left.\mathrm{N}^{\tau}-\mathrm{MH}\right)$ excretion is a nondestructive technique to quantify myofibrillar protein degradation under various physiological conditions. This technique has been validated in cattle 
(Harris and Milne, 1981; McCarthy et al., 1983). Gopinath and Kitts (1984) utilized $N^{2}$ MH excretion to measure myofibrillar protein degradation in growing steers. They concluded that rapid growth in steers is accompanied by a high rate of myofibrillar protein degradation. Alterations in the diet that cattle receive due to the availability of feedstuffs can affect the efficiency of production (Byers, 1980) and quality of the product (Aberle et al., 1981). Both alterations may be due to changes in the rate of muscle protein turnover. The objective of this study was to determine changes in the rate of myofibrillar protein degradation and estimated synthesis in cattle during periods of restricted feeding and subsequent realimentation.

\section{Materials and Methods}

Animals and Treatments. Twelve small to medium-framed, MARC III crossbred (1/4 Angus, 1/4 Hereford, 1/4 Pinzgauer and 1/4 Red Poll) steer calves with an average weight of $179 \mathrm{~kg}$ were weaned at approximately $230 \mathrm{~d}$ of age and given ad libitum access to a diet for 90 d. Throughout the study, the diet was composed on an "as-fed" basis of $36 \%$ com silage, $60 \%$ wet com and $4 \%$ supplement (supplement composition: $54 \%$ soybean meal, $17.9 \%$ corn, $21.7 \%$ limestone, $2 \%$ dicalcium phosphate, $3 \%$ urea, $.6 \%$ vitamin $A, .2 \%$ trace minerals, .5\% Rumensin containing $132 \mathrm{~g}$ monensin $/ \mathrm{kg}$ and $.1 \%$ sulfur) with a TDN of $84.16 \%$ and $10.93 \%$ crude protein.

After the preconditioning period, the study was initiated by randomly assigning the cattle to two treatments: 1) a group fed to gain approximately $.23 \mathrm{~kg} / \mathrm{d}$ for the first $80 \mathrm{~d}$, then given ad libitum access to feed for $66 \mathrm{~d}$ (RFC; $n=6$ ) or 2) given ad libitum access to the com and corn silage diet for $146 \mathrm{~d}$ (ALC; $n=6$ ). The cattle weighed approximately $285 \mathrm{~kg}$ at the initiation of the study. For the first $80 \mathrm{~d}$, the cattle fed the restricted diet were weighed twice each week to adjust feed intake to obtain the desired rate of gain. After the first $80 \mathrm{~d}$, all cattle were weighed every 2 wk and placed in metabolism crates. Daily gain of the cattle was calculated for the restriction and repletion

\footnotetext{
${ }^{4}$ Sigma Chemical Co., St. Louis, MO.

$5_{\text {Pickering Labs, Mountain View, CA. }}$
}

phases.

Urine and Serum Collection. At 27, 55, 97 , 118 and $146 \mathrm{~d}$ from the beginning of the study, cattle were weighed, placed in metabolism crates and allowed to adjust to the crates for 24 h. Urine was collected during the subsequent $24 \mathrm{~h}$ and weighed. Ten milliliters of $12 \mathrm{~N} \mathrm{HCl}$ were added to the urine as a preservative. A 150-ml sample was obtained for each collection period and frozen at $-20^{\circ} \mathrm{C}$ until it was analyzed. A $10-\mathrm{ml}$ blood sample was obtained via venipuncture, allowed to clot and centrifuged at $1,500 \times \mathrm{g}$ for $15 \mathrm{~min}$; the serum was frozen at $-20^{\circ} \mathrm{C}$ until it was analyzed.

Urine Analysis. Urine samples were thawed and their specific gravities were determined. Specific gravity was used to convert the weight of the 24-h urine collection to volume in order to determine the urine output for $24 \mathrm{~h}$. Urinary creatinine (C) concentration was determined using kits ${ }^{4}$ following a method (Sigma Chemical Company, 1983) that was a modification of the procedures of Slot (1965) and Heinegard and Tiderstrom (1973). Urinary urea nitrogen (UN) was measured using the procedure of Frankel et al. (1970). Total urinary nitrogen (TN) was quantitated using the Kjeldahl procedure (AOAC, 1985).

$\mathrm{N}^{\tau}$-methylhistidine concentration in the urine was determined using HPLC. Samples were prepared by diluting $100 \mu \mathrm{l}$ of urine with $10 \mu \mathrm{l} 30 \%$ sulfosalicylic acid. The sample was mixed for $5 \mathrm{~min}$ and centrifuged at $2,500 \times g$ for $15 \mathrm{~min}$. After centrifugation, $75 \mu \mathrm{l}$ of supernatant fractions were pipetted into a microfuge tube and $5 \mu \mathrm{l}$ of $4 \% \mathrm{NaOH}$ were added to adjust the $\mathrm{pH}$ to approximately 2.1 . An equal volume of Pickering Diluent ${ }^{5}$ containing norleucine $(.25 \mu \mathrm{mol} / \mathrm{ml})$ was added, gently mixed, and filtered (.2- $\mu \mathrm{m}$ screen) prior to filling HPLC loading vials. Separation and quantitation of $\mathrm{N}^{\tau}-\mathrm{MH}$ by HPLC was performed using a $3-\mathrm{mm} \times 250-\mathrm{mm}$ column containing $10-\mu \mathrm{m}$ cation exchange column ${ }^{5}$ with a 2-mm $\times 20-\mathrm{mm}$ guard column ${ }^{5}$. Temperature of the column was maintained at $42^{\circ} \mathrm{C}$ and injection volume of each sample was set at $5 \mu \mathrm{l}$. A three-step gradient was used to elute the amino acids as follows: $100 \% .24 \mathrm{~N}$ lithium citrate buffer, $\mathrm{pH} 2.75,70 \mathrm{~min} ; 65 \%$ $.24 \mathrm{~N}$ lithium citrate buffer and 35\% $.64 \mathrm{~N}$ lithium citrate buffer, $65 \mathrm{~min} ; 100 \% .64 \mathrm{~N}$ lithium citrate buffer, pH $7.50,50 \mathrm{~min}$. The column was regenerated between each sample by elution with the first buffer for $30 \mathrm{~min}$. 
Flow rate of the eluent was $.3 \mathrm{ml} / \mathrm{min}$. Postcolumn derivatization of $\mathbf{N}^{\tau}-\mathbf{M H}$ with orthophthaldehyde (1,2-benzene dicarbonal) was performed and the fluorescence was quantified using a spectrofluorometer ${ }^{6}$ with emission set at $338 \mathrm{~nm}$ and excitation set at $425 \mathrm{~nm}$.

Serum Analysis. Serum hydroxyproline (HYP) concentration was determined in thawed serum samples using the sample preparation procedures of Bannister and Bums (1970). Quantitation of HYP was performed using the procedure of Bergman and Loxley (1963). Albumin (A) concentration was measured by a method (Sigma Chemical Company, 1986) using the procedures of Doumas et al. (1971), Savory et al. (1976) and Corcoran and Duran (1977).

Calculations and Statistical Analysis. The calculations of the characteristics of muscle protein metabolism were performed according to Gopinath and Kitts (1984) and McCarthy et al. (1983). The $\mathrm{N}^{\tau}-\mathrm{MH}$ pool in skeletal muscle was calculated by multiplying the estimated skeletal muscle mass (33\% of body weight; Allen et al., 1968; Brannang, 1971) by the protein content of skeletal muscle mass (157 $\mathrm{mg} / \mathrm{g}$ fresh weight; Gopinath and Kitts, 1984) and the $\mathrm{N}^{\tau}-\mathrm{MH}$ content of skeletal muscle protein $\left(3.5106 \mu \mathrm{mol} \mathrm{N}^{\tau}-\mathrm{MH} / \mathrm{g}\right.$ muscle protein; Nishizawa et al,, 1979). The fractional breakdown rate (FBR) of muscle proteins was calculated by dividing the daily excretion of $\mathrm{N}^{\tau}-\mathrm{MH}$ in urine by the amount of $\mathrm{N}^{\tau}-\mathrm{MH}$ in the skeletal muscle pool and multiplying by 100.

Fractional accretion rate (FAR) was calculated as the rate of skeletal muscle protein gain divided by total skeletal muscle protein pool at the time urine samples were obtained. The calculation was: $\mathrm{FAR}=\left(\left[\mathrm{MP}_{1}-\mathrm{MP}_{0}\right] / \mathrm{T}\right) /$ $\left(\mathrm{MP}_{3}\right)$, where $\mathrm{MP}_{1}$ is the measure of total muscle protein $14 \mathrm{~d}$ after sampling, $\mathrm{MP}_{0}$ is the measure of muscle protein $14 \mathrm{~d}$ before sampling, $T$ is $28 \mathrm{~d}$ and $\mathrm{MP}_{3}$ is the total muscle protein at sampling time. The numerator of the FAR equation is equal to the absolute rate of muscle protein accretion (MPA).

The fractional synthesis rate (FSR) of the mixed muscle protein pool was calculated as the sum of FBR and FAR. Measurement of $\mathrm{N}^{\tau}$-MH excretion can be used to determine degradation of myofibrillar proteins, primarily

\footnotetext{
${ }^{6}$ Waters, Milford, MA.
}

actin (Young and Munro 1978). However, the differences in turnover rate between myofibrillar, sarcoplasmic and stromal proteins are not major enough to negate the use of $\mathrm{N}^{\tau}-\mathrm{MH}$ excretion to mark skeletal muscle protein breakdown (Bates and Millward, 1983). Thus, $\mathrm{N}^{\tau}$-MH excretion is useful as an estimate of muscle protein tumover. This calculation is a modification of the calculation used by Millward et al. (1975), who used the FSR and FAR to calculate FBR. Myofibrillar protein degradation (MPD) was calculated by dividing the daily $\mathrm{N}^{\tau}-\mathrm{MH}$ excretion by the concentration of $\mathrm{N}^{\tau}-\mathrm{MH}$ in muscle. The rate of muscle protein synthesis (MPS) was calculated as the sum of MPD and MPA.

Data were analyzed using an analysis of variance with a sequential, split-plot treatment design (Steel and Torrie, 1980). The Least Significant Difference (LSD) method was used to compare treatment means at $P<.05$. A modified $t$-statistic was calculated to allow whole and subplot comparisons. Age-related differences were determined by analyzing the data of the ALC by analysis of variance. Linear, quadratic and cubic contrasts were determined at $P<.05$. Treatment means, standard deviations and analysis of variance were calculated and performed using SAS (1985).

\section{Results and Discussion}

The ALC cattle had higher $(P<.05)$ ADG than RFC during the restricted phase (1.25 vs $.61 \mathrm{~kg} / \mathrm{d})$, but ADG were not different $(P>$ $.05)$ after realimentation ( 1.35 vs $1.51 \mathrm{~kg} / \mathrm{d})$. Cattle with ad libitum access to feed had a higher $(P<.05)$ urinary $\mathbf{N}^{\tau}-\mathrm{MH}$ excretion during the first two collection periods; however, it was lower $(P<.05)$ for ALC than for RFC at $118 \mathrm{~d}$ and not different at $146 \mathrm{~d}$ (Table 1). The quantities of $\mathrm{N}^{\tau}$-MH excreted by our steers (Table 1) were in a range similar to that reported by McCarthy et al. (1983) and Gopinath and Kitts (1984) but slightly higher than reported by Nishizawa et al. (1979) and Harris and Milne (1981). The ALC showed a linear decrease $(P<.05)$ in $\mathrm{N}^{\tau}$-MH excretion in response to age or weight. This decrease may reflect the decline in degradation rates as the animals grow. Several researchers have observed age-related declines in FBR (Waterlow and Stephens, 1968; Millward et al., 
TABLE 1. DAILY URINARY $\mathbf{N}^{\tau}$-METHYLHISTIDINE, CREATININE, UREA NITROGEN AND TOTAL URINARY NITROGEN EXCRETION IN CATTLE GIVEN AD LIBITUM OR RESTRICTED ACCESS TO FEED ${ }^{\mathrm{a}}$

\begin{tabular}{|c|c|c|c|c|}
\hline Item and sample time $\mathrm{e}^{\mathrm{b}}$ & Ad libitum ${ }^{c}$ & Restricted $^{d}$ & Sig. & SE \\
\hline $\begin{array}{l}N^{2} \text {-methylhistidine, mmo } \\
27 \mathrm{~d} \\
55 \mathrm{~d} \\
97 \mathrm{~d} \\
118 \mathrm{~d} \\
146 \mathrm{~d}\end{array}$ & $\begin{array}{l}2.19 \\
2.00 \\
2.43 \\
2.43 \\
1.78\end{array}$ & $\begin{array}{l}1.56 \\
1.32 \\
2.37 \\
3.07 \\
2.38\end{array}$ & $\begin{array}{l}* \\
* \\
*\end{array}$ & .09 \\
\hline $\begin{array}{l}\text { Creatinine, } g / d \\
27 \mathrm{~d} \\
55 \mathrm{~d} \\
97 \mathrm{~d} \\
118 \mathrm{~d} \\
146 \mathrm{~d}\end{array}$ & $\begin{array}{r}7.88 \\
9.14 \\
10.36 \\
12.00 \\
11.53\end{array}$ & $\begin{array}{l}7.36 \\
7.16 \\
8.78 \\
9.98 \\
9.41\end{array}$ & $\begin{array}{l}* \\
* \\
*\end{array}$ & .31 \\
\hline $\begin{array}{l}\text { Urea nitrogen, } g / d \\
27 \mathrm{~d} \\
55 \mathrm{~d} \\
97 \mathrm{~d} \\
118 \mathrm{~d} \\
146 \mathrm{~d}\end{array}$ & $\begin{array}{l}.95 \\
2.14 \\
2.68 \\
3.46 \\
4.71\end{array}$ & $\begin{array}{r}.76 \\
1.01 \\
1.00 \\
2.11 \\
3.39\end{array}$ & $\begin{array}{l}* \\
* \\
* \\
*\end{array}$ & .198 \\
\hline $\begin{array}{l}\text { Total urinary nitrogen, } g / \\
27 \mathrm{~d} \\
55 \mathrm{~d} \\
97 \mathrm{~d} \\
118 \mathrm{~d} \\
146 \mathrm{~d}\end{array}$ & $\begin{array}{l}25.83 \\
40.24 \\
45.68 \\
55.50 \\
64.84\end{array}$ & $\begin{array}{l}20.63 \\
19.79 \\
26.72 \\
41.35 \\
58.43\end{array}$ & * & 2.40 \\
\hline
\end{tabular}

${ }^{a}$ Each treatment contained six cattle.

Days from initiation of the study.

${ }^{\mathrm{c} C a t t l e}$ were offered ad libitum access to corn and com silage diet (1.36 kg/d, daily gain).

${ }^{d}$ Restricted cattle were held at $.23 \mathrm{~kg} / \mathrm{d}$ (daily gain) for the first $80 \mathrm{~d}$ of the study then offered ad libitum access to a corn and corn silage diet for the remainder of the study.

eValues in a row marked with an asterisk differ $(P<.05)$.

1975). Urinary $C$ excretion was higher $(P<$ .05) in ALC than in RFC during the last four sampling periods and increased linearly $(P<$ .05 ) as the ALC aged (Table 1). Higher creatinine excretion in the ALC indicates that muscle mass was greater for ALC animals. Urinary UN and TN excretions were higher ( $P$ $<.05)$ by ALC than by RFC at d 55, 97 and 118; UN also was higher $(P<.05)$ at $146 \mathrm{~d}$ (Table 1). Urinary $T N$ and urinary $U N$ differences indicate differences in the rate of catabolism of endogenous and exogenous proteins. One additional reason for lower values of urinary UN and TN for the RFC is that lower amounts of protein were consumed by the cattle during feed restriction (d 0 to 80 ). Protein content of the diet has a dramatic effect on urinary $\mathrm{N}$ excretion. However, increased protein accretion may have caused the continued lower excretions seen in the RFC after d 80 during feed repletion.
Body weights of ALC were higher $(P<.05)$ than those of restricted-fed cattle at the last four sampling periods (Table 2). A linear ( $P<$ $.05)$ increase in body weight of ALC with age was observed. There was no difference $(P>$ 0.5 ) between ALC and RFC in body weight to creatinine ratio (Table 2). This observation suggests that muscle mass per unit of body weight was not different, regardless of dietary treatment. However, this ratio declined numerically at $146 \mathrm{~d}$ in both treatments, possibly reflecting an increase in fat content of the cattle. When expressed as a ratio to body weight or to creatinine, $\mathrm{N}^{\tau}$-MH excretion was higher $(P<.05)$ for RFC than for AFC during the last two collection periods (Table 2). When expressed in this manner, $\mathrm{N}^{\tau}-\mathrm{MH}$ should be an indicator of the amount of myofibrillar protein degradation per muscle mass.

Myofibrillar Protein Turnover. Quantification of an animal's muscle mass is necessary 
TABLE 2. RELATIONSHIP BETWEEN BODY WEIGHT, $\mathrm{N}^{t}$-METHYLHISTIDINE AND CREATININE EXCRETION IN CATTLE GIVEN AD LIBITUM OR RESTRICTED ACCESS TO FEED ${ }^{\mathrm{a}}$

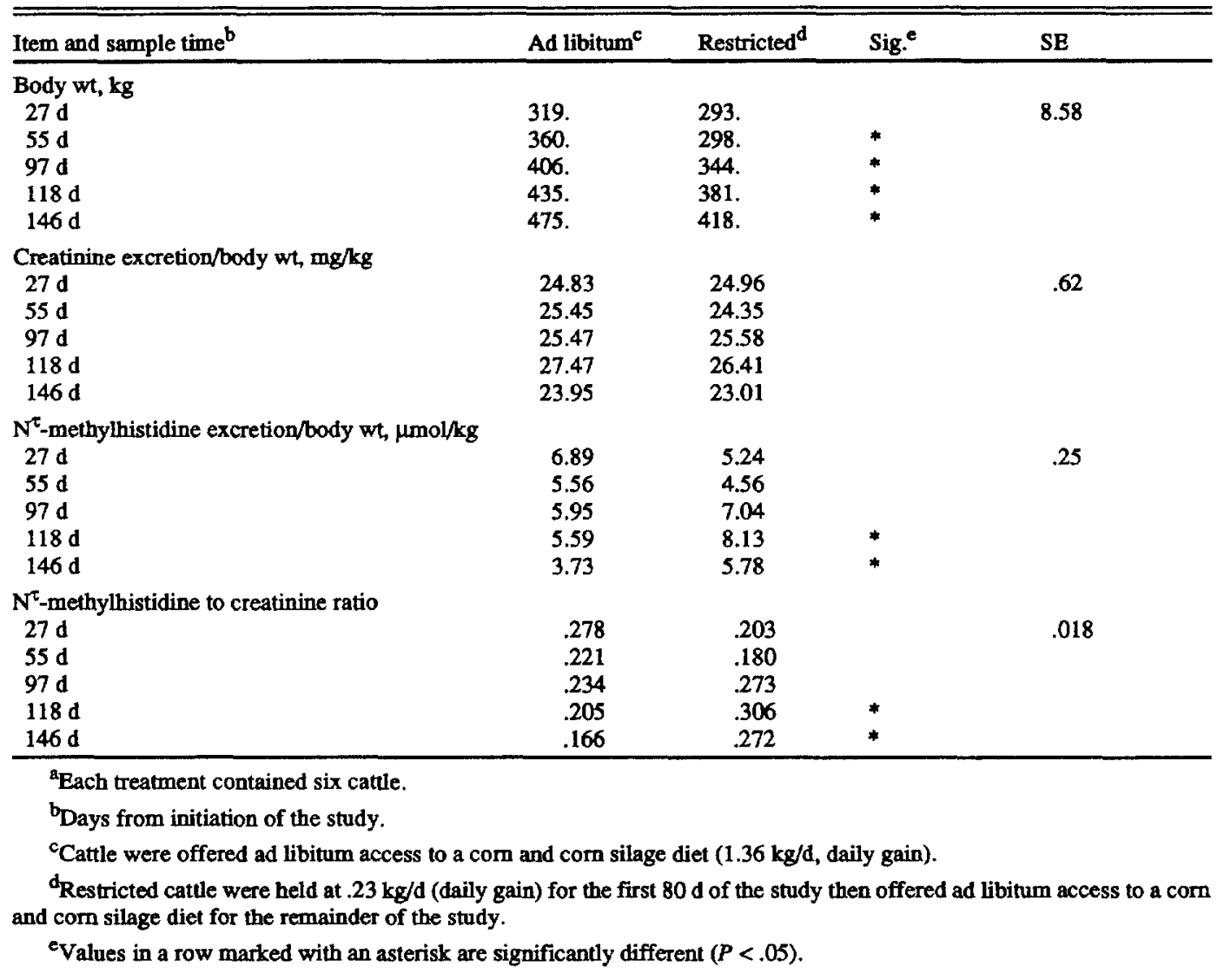

to estimate FBR, FSR and FAR. Several attempts to accurately determine muscle mass have had limited success. Munro (1969) reported that most mammals have between $\mathbf{4 0}$ and $50 \%$ muscle in their bodies, regardless of species or sex of the animals. However, in ruminants, particularly cattle, most reports estimate muscle mass to be between 31 and $35 \%$ of body weight (Henricksen et al., 1965; Allen et al., 1968; Brannang, 1971; Nishizawa et al., 1979). In the present study, muscle mass was assumed to be $33 \%$ of body weight (Allen et al., 1968). Based on this value, the FBR we observed was similar to data reported by McCarthy et al. (1983), 2.46 to $3.42 \% / d$, but slightly higher than data reported by Gopinath and Kitts (1984), 2.07 to $2.84 \% /$ d. Results indicate that FBR was higher $(P<.05)$ for RFC than for ALC after realimentation (Table 3 ). These results are similar to those of Haverberg et al. (1975), who observed that rats previously deprived of protein or energy exhibited a marked increase in FBR upon repletion. The RFC had lower $(P<.05)$ FSR at $27 \mathrm{~d}$ but higher FSR $(P<.05)$ at 118 and 146 d. These data indicate that feed restriction suppresses FSR whereas repletion increases FSR. Millward et al. (1975) observed that rates of protein synthesis in rats fed a marginally deficient diet were reduced. However, upon realimentation, muscle protein synthesis increased rapidly. Data from our study follow a similar trend.

The RFC had lower $(P<.05)$ MPD and muscle protein synthesis (MPS) at periods of nutrient restriction but higher $(P<.05)$ MPD and MPS at $118 \mathrm{~d}$, during the period ( $>80 \mathrm{~d}$ ) of repletion (Table 4). Millward (1980) suggested that the rate of MPD may be elevated during periods of rapid growth or during conditions that cause muscle wasting.

Remodeling of myofibrils, which occurs at various stages of growth, probably is the cause 
TABLE 3. SKELETAL MUSCLE $N^{\tau}$-METHYLHISTIDINE POOL, FRACTIONAL BREAKDOWN, ACCRETION AND SYNTHESIS RATES IN CATTLE GIVEN AD LIBITUM OR RESTRICTED ACCESS TO FEED ${ }^{a}$

\begin{tabular}{|c|c|c|c|c|}
\hline Item and sample time ${ }^{b}$ & Ad libitum ${ }^{\mathrm{c}}$ & Restricted $^{\mathrm{d}}$ & Sig. ${ }^{\mathrm{e}}$ & SE \\
\hline \multicolumn{5}{|c|}{ Skeletal muscle $\mathrm{N}^{\tau}$-methylhistidine pool, mmol f } \\
\hline $27 \mathrm{~d}$ & 58.05 & 53.45 & & 1.56 \\
\hline $55 \mathrm{~d}$ & 65.49 & 54.29 & * & \\
\hline $97 \mathrm{~d}$ & 73.86 & 62.70 & * & \\
\hline $118 \mathrm{~d}$ & 79.24 & 69.34 & * & \\
\hline $146 d$ & 86.45 & 76.20 & * & \\
\hline \multicolumn{5}{|l|}{ Fractional breakdown rate, $\% / \mathrm{d}^{\mathrm{f}}$} \\
\hline $27 \mathrm{~d}$ & 3.79 & 2.87 & & .14 \\
\hline $55 \mathrm{~d}$ & 3.05 & 2.50 & & \\
\hline $97 \mathrm{~d}$ & 3.26 & 3.87 & & \\
\hline $118 \mathrm{~d}$ & 3.07 & 4.46 & * & \\
\hline $146 \mathrm{~d}$ & 2.04 & 3.17 & * & \\
\hline \multicolumn{5}{|l|}{ Fractional accretion rate, $\% / \mathrm{d}^{\mathrm{f}}$} \\
\hline $27 \mathrm{~d}$ & .53 & .26 & * & .028 \\
\hline $55 \mathrm{~d}$ & .16 & .14 & & \\
\hline $97 \mathrm{~d}$ & .18 & .43 & $*$ & \\
\hline $118 \mathrm{~d}$ & .32 & .40 & & \\
\hline $146 \mathrm{~d}$ & .34 & .38 & & \\
\hline \multicolumn{5}{|l|}{ Fractional synthesis rate, $\% / \mathrm{d}^{\mathrm{g}}$} \\
\hline $27 \mathrm{~d}$ & 4.32 & 3.14 & * & .294 \\
\hline $55 \mathrm{~d}$ & 3.21 & 2.65 & & \\
\hline $97 \mathrm{~d}$ & 3.45 & 4.30 & & \\
\hline $118 \mathrm{~d}$ & 3.40 & 4.86 & * & \\
\hline $146 \mathrm{~d}$ & 2.39 & 3.55 & * & \\
\hline
\end{tabular}

${ }^{a}$ Each treatment contained six cattle.

bDays from initiation of the study.

${ }^{c}$ Cattle were offered ad libitum access to a com and corn silage diet $(1.36 \mathrm{~kg} / \mathrm{d}$, daily gain).

${ }^{d}$ Restricted cattle were held at $.23 \mathrm{~kg} / \mathrm{d}$ (daily gain) for the first $80 \mathrm{~d}$ of the study then offered ad libitum access to a corn and corn silage diet for the remainder of the study.

eValues in a row marked with an asterisk are significantly different $(P<.05)$.

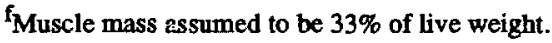

${ }^{8}$ The summation of fractional breakdown rate and fractional accretion rate.

of increased rates of MPD (Goldspink, 1970; Millward et al., 1975). Increased MPS and MPD during repletion of the RFC, indicates that protein tumover rates were high in conjunction with increased growth rate. The increased rate of muscle protein tumover during repletion phase suggests that dietary requirements of energy also may be higher.

Serum Analysis. The synthesis of serum albumin accounts for about $10 \%$ of total liver protein synthesis (Morgan and Peters, 1971). Changes in albumin concentration can be useful as an index of amino acid flux and protein metabolism in the liver. The decrease $(P<.05)$ in serum albumin levels observed in RFC at $55 \mathrm{~d}$ could be attributed to a decrease in synthesis of albumin due to a dietary protein deficiency (Table 5). Several researchers have observed decreased synthesis of albumin and albumin messenger-RNA in response to a deficiency of dietary protein (JeeJeebhoy et al., 1975; Pain et al., 1978). When RFC were realimented, serum albumin levels were not different $(P<.05)$ from ALC from $97 \mathrm{~d}$ through $146 \mathrm{~d}$. Free-HYP in serum was higher $(P<.05)$ in the RFC cattle during the first two collection periods. There also was a linear decline $(P<.05)$ of AFC in serum free-HYP as animals aged. Higher concentrations of HYP in the serum of the RFC during restriction or at times of slow growth is contradictory to the data of Kivirikko (1970), who reported that during rapid rates of growth, serum HYP increased. One possible explanation for these differences is that the animal at maintenance is synthesizing collagen, which is 
TABLE 4. ABSOLUTE RATE OF MUSCLE PROTEIN DEGRADATION, ACCRETION AND SYNTHESIS IN CATTLE GIVEN AD LIBITUM OR RESTRICTED ACCESS TO FEED ${ }^{2}$

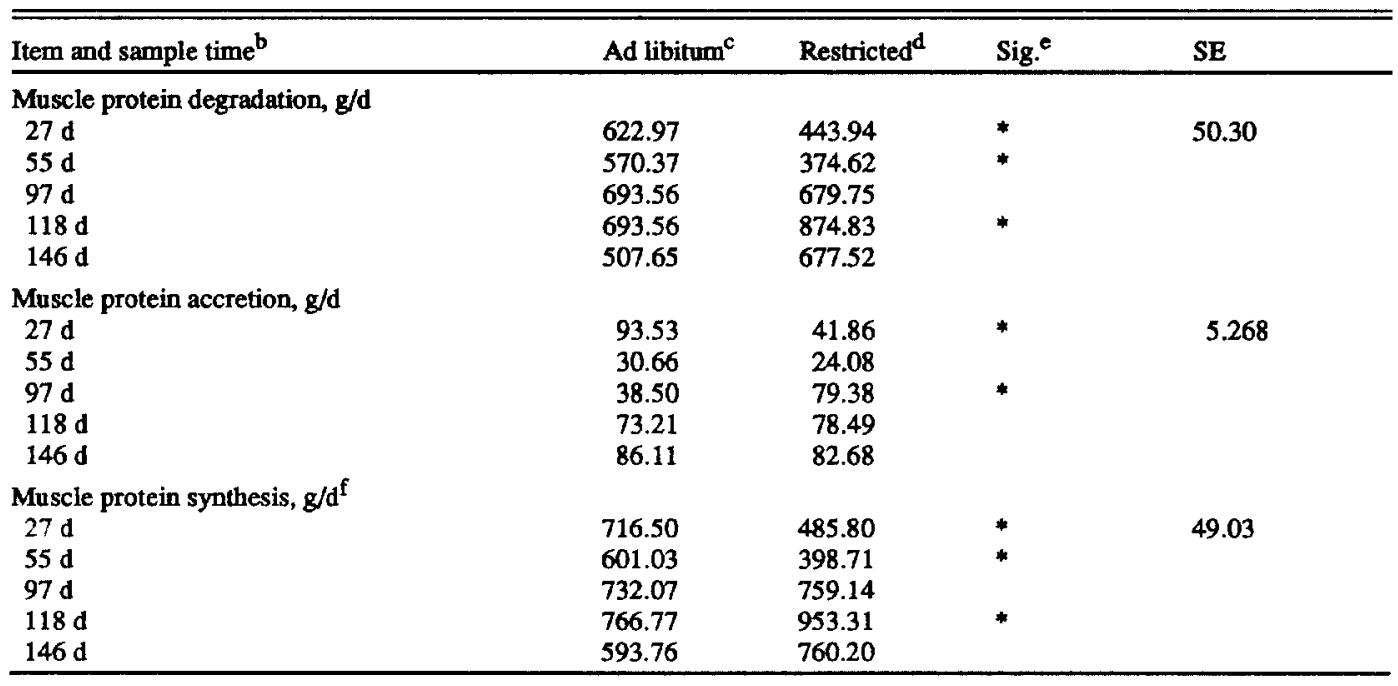

${ }^{a}$ Each treatment contained six cattle.

bays from initiation of the study.

c Cattle were offered ad libitum access to a com and corn silage diet (1.36 kg/d, daily gain).

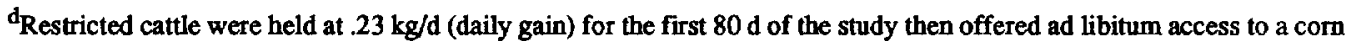
and corn silage diet for the remainder of the study.

${ }^{e}$ Values in a row marked with an asterisk are significantly different $(P<.05)$.

${ }^{f}$ The summation of muscle protein degradation and muscle protein accretion.

TABLE 5. SERUM ALBUMIN AND FREE HYDROXYPROLINE IN CATTLE GIVEN AD LIBITUM OR RESTRICTED ACCESS TO FEED ${ }^{\mathrm{a}}$

\begin{tabular}{|c|c|c|c|c|}
\hline Item and period ${ }^{b}$ & Ad libitum ${ }^{c}$ & Restricted $^{\mathrm{d}}$ & Sig. & SE \\
\hline \multicolumn{5}{|l|}{ Albumin, $g / d 1$} \\
\hline $27 \mathrm{~d}$ & 3.94 & 4.15 & & .057 \\
\hline $55 \mathrm{~d}$ & 4.06 & 3.52 & $\star$ & \\
\hline $97 \mathrm{~d}$ & 4.11 & 4.02 & & \\
\hline $118 d$ & 4.32 & 4.11 & & \\
\hline $146 d$ & 4.49 & 4.55 & & \\
\hline \multicolumn{5}{|c|}{ Free hydroxyproline, $\mathrm{g} / \mathrm{ml}$} \\
\hline $27 \mathrm{~d}$ & 5.43 & 8.12 & $*$ & .31 \\
\hline $55 \mathrm{~d}$ & 4.31 & 6.75 & * & \\
\hline $97 \mathrm{~d}$ & 4.43 & 3.89 & & \\
\hline $118 \mathrm{~d}$ & 4.28 & 2.87 & & \\
\hline $146 \mathrm{~d}$ & 2.82 & 2.74 & & \\
\hline
\end{tabular}

Each treatment contained six cattle.

bays from initiation of the study.

cCattle were offered ad libitum access to a com and corn silage diet ( $1.36 \mathrm{~kg} / \mathrm{d}$, daily gain).

${ }^{d_{R}}$ estricted cattle were held at $.23 \mathrm{~kg} / \mathrm{d}$ (daily gain) for the first $80 \mathrm{~d}$ of the study then offered ad libitum access to a corn and com silage diet for the remainder of the study.

eValues in a row marked with an asterisk are significantly different $(P<.05)$. 
readily degraded intracellularly to provide a protein source to sustain other, more important, maintenance functions of the body.

\section{Implications}

Restricting and repleting cattle changed the rate of muscle protein turnover; these changes may influence the efficiency of cattle growth. Myofibrillar protein degradation and synthesis decreased during the restriction period and increased following subsequent repletion. Muscle protein synthesis and accretion increased early during repletion, indicating that repleted cattle may have greater efficiency in reaching finishing weights. This information is valuable in understanding the changes in muscle protein metabolism that occur in cattle whose nutritional plane is varied.

\section{Literature Clted}

Aberle, E. D., E. S. Reeves, M. D. Judge, R. E. Hunsley and T. W. Perry. 1981. Palatability and muscle characteristics of cattle with controlled weight gain: Time on a high energy diet. J. Anim. Sci. 52:757.

Allen, D. M., R. A. Merkel, W. T. Magee and R. H. Nelson. 1968. Variation in some beef carcass compositional characteristics within and between selected weight and fat thickness ranges. J. Anim. Sci. 27:1239.

AOAC. 1985. Official Methods of Analysis (14th Ed.). Association of Official Analytical Chemists, Washington, DC.

Bannister, S. and G. Bums. 1970. Determination of plasma hydroxyproline. Analyst 95:596.

Bates, P. C. and D. J. Millward. 1983. Myofibrillar protein turnover: synthesis rates of myofibrillar and sarcoplasmic protein fractions in different muscles and the changes observed during postnatal development and in response to feeding and starvation. Biochem. J. 214: 587.

Bergman, I. and R. Loxley. 1963. Two improved and simplified methods for the spectrophotometric determination of hydroxyproline. Anal. Chem. 35:1961.

Brannang, E. 1971. Studies on monozygous cattle twins. XXIII. The effect of castration and age of castration on the development of single muscles, bones and special sex characters. Part II. Swed. J. Agric. Res. 1:69.

Byers, F. M. 1980. Systems of beef cattle feeding and management to regulate composition. Ohio Agric. Res. and Dev. Center, Beef Cattle Nutrition and Growth - A Summary of Research. Research Circular 258. p 1.

Corcoran, R. and S. Duran. 1977. Albumin determination by a modified bromcresol green method. Clin. Chem. 23: 765.

Daniel, P. M., O. E. Pratt and E. Spargo. 1977. The metabolic homeostatic role of muscle and its function as a store of protein. Lancet 2:446.

Doumas, B., W. Watson, and H. Biggs. 1971. Albumin standards and the measurement of serum albumin with bromcresol green. Clin. Chim. Acta 31:87.

Frankel, S., S. Reitman and A. C. Sonnenwirth. 1970. In:
Gradwohl's Clinical Laboratory Methods and Diagnosis (7th Ed.). Vol. 1. p 340.

Goldspink, G. 1970. The proliferation of myofibrils during muscle fiber growth. J. Cell Sci. 6:593.

Gopinath, R. and W. D. Kitts. 1984. Growth, $N^{\tau}$ methylhistidine excretion and muscle protein degradation in growing beef steers. J. Anim. Sci. 59:1262.

Harris, C. I. and G. Milne. 1981. The urinary excretion of $N^{\tau}$-methylhistidine by cattle: validation as an index of muscle protein breakdown. Br. J. Nutr. 45:411.

Haverberg, L. N., L. Deckelbaum, C. Bilmazes, H. N. Munro and V. R. Young. 1975. Myofibrillar protein turnover and urinary $\mathbf{N}^{\tau}$-methylhistidine output. Biochem. $J$. 152:503.

Heinegard, D. Z. and G. Tiderstrom. 1973. Determination of serum creatinine by a direct coloriometric method. Clin. Chim. Acta 43:305.

Henrickson, R. L., L. S. Pope and R. F. Hendrickson. 1965. Effect of rate of gain of fattening beef calves on carcass composition. J. Anim. Sci. 24:507.

JeeJeebhoy, K. N., J. Ho, G. R. Greenburg, M. J. Phillips, A. B. Robertson and U. Sodtke. 1975. Albumin, fibrinogen, and transferrin synthesis in isolated rat hepatocyte suspensions. Biochem. J. 146:141.

Kivirikko, K. I. 1970. Urinary excretion of hydroxyproline in health and disease. Int. Rev. Connect. Tissue Res. 5: 93.

McCarthy, F. D., W. D. Bergen and D. R. Hawkins. 1983. Muscle protein turnover in cattle of differing genetic backgrounds as measured by urinary $N^{\tau}$-methylhistidine excretion. J. Nutr. 113:2455.

Millward, D. J. 1980. Protein degradation in muscle and liver. In: M. Florkin and E. H. Stotz (Ed.) Comprehensive Biochemistry: Protein Metabolism Volume 19B, Part 1.p 153. Elsevier Scientific Publishing Co., New York.

Millward, D. J., P. J. Garlick. R.J.C. Stewart, D. O. Nnanyelugo and J. C. Waterlow. 1975. Skeletalmuscle growth and protein turnover. Biochem. J. 150: 235.

Morgan, E. H. and T. Peters, Jr. 1971. The biosynthesis of rat serum albumin. J. Biol. Chem. 246:3500.

Munro, H. N. 1969. The evolution of protein metabolism in mammals. In: H. N. Munro (Ed.) Mammalian Protein Metabolism (Vol 3). p 151, Academic Press, New York.

Nishizawa, N., Y. Toyoda, T. Noguchi, S. Hareyama, H, Itabashi and $\mathbf{R}$. Funabiki. 1979. $\mathbf{N}^{\tau}$-methylhistidine content of organs and tissues of cattle and an attempt to estimate fractional catabolic and synthetic rates of myofibrillar proteins of skeletal muscle during growth by measuring urinary output of $\mathrm{N}^{\tau}$-methylhistidine. Br. J. Nutr. 42:247.

Pain, V. M., M. J. Clemens and P. J. Garlick. 1978. The effect of dietary protein deficiency on albumin synthesis and on concentration of active albumin messenger ribonucleic acid in rat liver. Biochem. J. 172:129.

SAS. 1985. SAS User's Guide: Statistics. SAS Inst., Inc. Cary, NC.

Savory, J., M. G. Heintges, M. Sonowane, and R. E. Cross. 1976. Measurement of total protein and albumin in serum with a centrifugal analyzer. Clin. Chem. 22: 1102.

Sigma Chemical Co. 1983. Creatinine. Tech. Bull. No. 555 (Rev. Ed.). St. Louis, MO.

Sigma Chemical Co. 1986. Albumin. Tech. Bull. No. 631. 
St. Louis, MO.

Slot, C. 1965. Plasma creatinine determination: A new and specific Jaffe reaction method. Scand. J. Clin. Lab. Invest. 17:381.

Steel, R.G.D. and J. H. Torrie. 1980. Principles and Procedures of Statistics: A Biometrical Approach (2nd Ed.). McGraw-Hill Book Co., New York.
Waterlow, J. C. and J.M.L. Stephens. 1968. The effect of low protein diets on the turnover rates of serum, liver and muscle proteins in the rat, measured by continuous infusion of L- $\left[{ }^{14}\right.$ C $]$ lysine. Clin. Sci. 35:287.

Young, V. R. and H. N. Munro. 1978. $N^{\tau}$-Methylhistidine (3-methylhistidine) and muscle protein turnover: an overview. Fed. Proc. 37:2291. 